\title{
JUSTICIABILITY OF LEGISLATIVE PROCEEDINGS: A LEGAL ANALYSIS OF THE MALAYSIAN COURTS' APPROACH
}

\author{
Hunud Abia Kadouf* \& \\ Abdulfatai O. Sambo**
}

\begin{abstract}
The issue of whether courts can review legislative processes has always been at centre stage in constitutional discourse. Sometimes, some members of the legislature, being aggrieved on certain decisions or procedures the leadership of the House adopts in a situation, approach the courts for its intervention. Yet, Malaysian legal and constitutional frameworks seem to be that proceedings of the legislature are not justiciable. Based on this premise, the paper is intended to analyse the Malaysian courts' approach towards actions brought to challenge certain proceedings of the legislature by the aggrieved members. To achieve this, the paper analyses issues relating to suspension of legislative members; removal of legislative members from
\end{abstract}

\footnotetext{
* $\quad$ Professor \& Dean, Ahmad Ibrahim Kulliyyah of Laws, International Islamic University Malaysia (IIUM). E-mail: hunud@iium.edu.my.

** LL.B, LL.M, Ph.D. (IIUM, Malaysia), Post-doctoral Researcher, AIKOL, IIUM \& Lecturer, Public Law Dept., University of Ilorin-Nigeria. E-mail: fataisambo@yahoo.com.
} 
committees or as principal members; disqualification of legislative members; injunction to stop the proceedings of the legislature; and confirmatory proceedings of the legislature. It uses provisions of Malaysian Constitution, courts' decisions and opinions of experts to enrich this study. The paper finds that courts' attitude has been largely that of the hands' tied approach despite sufficient constitutional stings in members' actions which should have justified the courts' intervention.

Keywords: Justiciability, legislative proceedings, courts, Malaysia.

\title{
KEBOLEHADILAN PROSIDING PERUNDANGAN: ANALISIS UNDANG-UNDANG KE ATAS PENDEKATAN MAHKAMAH MALAYSIA
}

\begin{abstract}
ABSTRAK
Isu sama ada mahkamah boleh mengkaji semula proses perundangan sentiasa berada di pentas utama dalam wacana perlembagaan. Kadangkala, sesetengah ahli badan perundangan, yang terkilan dengan keputusan atau prosedur tertentu yang diambil oleh kepimpinanan Dewan dalam sesuatu keadaan, akan meminta agar mahkamah campur tangan. Namun, kerangka perundangan dan perlembagaan Malaysia menampakkan yang prosiding perundangan tidak boleh diadili. Atas dasar ini, penulisan ini adalah bertujuan menganalisa pendekatan mahkamah Malaysia terhadap tindakan yang diambil untuk mencabar prosiding tertentu badan perundangan oleh ahli yang terkilan. Bagi mencapai maksud tersebut, penulisan ini menganalisa isu-isu berkaitan dengan penggantungan ahli badan perundangan;
\end{abstract}


penyingkiran ahli dewan perundangan daripada jawatankuasa atau sebagai ahli utama; pengisytiharan ketaklayakan ahli dewan perundangan; tindakan injunksi bagi menahan prosiding badan perundangan; dan prosiding pengesahan oleh badan perundangan. Ia menggunakan peruntukan Perlembagaan Malaysia, keputusan mahkamah dan pendapat pakar bagi memperkayakan hasil kajian ini. Penulisan ini mendapati bahawa sikap mahkamah, secara umumnya, adalah mengambil pendekatan 'tangan terikat' walaupun terdapat sengat perlembagaan yang mencukupi dalam tindakan ahli badan yang sepatutnya mewajarkan campurtangan mahkamah.

Kata kunci: kebolehadilan, prosiding perundangan, mahkamah, Malaysia.

\section{INTRODUCTION}

One major problem which faces today's judiciary in many jurisdictions is the best and legitimate way to decide matters with high political undertones. This is perhaps the reason why deciding matters relating to affairs or actions of the legislature are sometimes problematic. The courts may decide the matters brought before it for exercise of judicial review on the merit thus serving the interest of justice. In this situation, the courts may be accused of usurping the powers of the legislature by dabbling into legislative affairs. On the other hand, the court may decline the exercise of its judicial review power. Here, the court can also be accused of not serving the interest of justice as it has abdicated its ordained duties of resolving disputes in one way or the other no matter whose ox is gored. In fact, as cases will later show, some legislative members have approached the courts for intervention when they felt aggrieved by certain decisions taken by 'leadership' or powerful members of the house. Sometimes, the issues might be suspension of legislative members or their removal from committees or as principal members. In some other instances, the issue submitted for courts' intervention borders on disqualification of legislative members. At times, courts' injunctions to stop the proceedings of the legislature have been sought. Despites these 
issues, the courts seem not to have come up with concrete and acceptable framework in resolving these disputes.

Against the above backdrop, the objective of this paper is to analyse the exercise of the powers of judicial review on matters pertaining to legislative proceedings. It first gives a detailed account of the legal framework on legislative actions. It will reveal whether the courts have treated issues relating to internal affairs of the legislature as political questions not fit for judicial determination or the courts have exercised powers of review in this regard. In analysing judicial review affecting legislative actions, the paper discusses, using judicial decisions, the exercise of judicial review power as affecting internal affairs of the legislature. Thus, this paper analyses issues relating to suspension of legislative members; removal of legislative members from committees or as principal members; disqualification of legislative members; injunction to stop the proceedings of the legislature; and confirmatory proceedings of the legislature. The paper also examines the exercise of judicial review power as affecting removal of the executive otherwise known as loss of confidence proceedings of the legislature and matters relating to the expediency or motive behind the exercise of legislative actions.

\section{THE LEGAL FRAMEWORK ON LEGISLATIVE PROCESSES}

The Malaysian Federal Constitution creates and vests the legislative authority of the Federation in the Parliament. ${ }^{1}$ The State Legislative Assemblies also make laws for the States. ${ }^{2}$ The Constitution empowers the Parliament ${ }^{3}$ to regulate its own procedure and is therefore not subject to external regulation. It provides that: "subject to the provision of this

\footnotetext{
1 See Article 44 of the Malaysian Federal Constitution.

2 Ibid. See Eighth Schedule, [Article 71], Part 1, section 3 of the Federal Constitution. It makes law with respect to matters enumerated in State List and Concurrent List. See Article 95 B (1) List II and List III.

3 The Parliament is vested with legislative powers in the Federation of Malaysia and can make laws in respect of matters contained in the Federal legislative list. See Article 44 of the Federal Constitution of Malaysia.
} 
Constitution and of Federal Law, each House of Parliament shall regulate its own procedure." ${ }^{4}$ The Constitution also goes further to limit the powers of the court to entertain matters relating or pertaining to the internal proceedings of the House. It provides that: "The validity of any proceedings in either House of Parliament or any Committee thereof shall not be questioned in any court." 5 Similarly, for the States, apart from the fact that each State in Malaysia is constitutionally empowered to regulate its own procedure, ${ }^{6}$ there is also a corresponding provision contained in the Constitution which precludes the court from entertaining any matter relating or pertaining to the proceedings of the State Legislative Assemblies. It provides that: "The validity of the proceedings in the Legislative Assembly of any State shall not be questioned in any Court."

Similarly, the Speaker and Deputy Speaker of the House of Representatives may be removed from office at any time the House so 'resolves. ${ }^{8}$ The type of resolution required is not stated but the House has the right to decide this under the Constitution. ${ }^{9}$ However, the removal of the President of the Senate and Deputy President of the Senate by the Senate is not expressly stated even though there are provisions for their resignation and disqualification. ${ }^{10}$ The decisions of the Senate or the House as to the disqualification of the President of the Senate, Deputy

$4 \quad$ See Article 62 of the Federal Constitution. The State Legislative Assemblies also have provisions in each States constitutions empowering them to regulate their proceedings.

$5 \quad$ See Article 63 of the Federal Constitution.

$6 \quad$ See Article 27(1) $2^{\text {nd }}$ Part of the Constitution of the State of Johore; Article 57(1) Part III of the Constitution of the State of Kedah; Article 44(1) of the Constitution of the State of Kelantan; Article 24(1) of the Constitution of the State of Malacca; Article 60(1) of the Constitution of the State of Negeri Sembilan; Article 30(1) of the Constitution of the State of Pehang; Article 24(1) of the Constitution of the State of Penang; Article 44(1) of the Constitution of the State of Perak; Article 59(1) of the Constitution of the State of Perlis; Article 24(1) of the Constitution of the State of Sabah; Article 24(1) of the Constitution of the State of Sarawak; Article 75(1) and 36 of the Constitution of the State of Selangor; Article 42(1) of the Constitution of the State of Trengganu.

7 See Article 72 of the Federal Constitution of Malaysia.

8 See Articles 57(2) (c) and (2A) (b) of the Federal Constitution. See Article 62(4) of the Federal Constitution.

$10 \quad$ See generally Article 56. 
President of the Senate and Speaker and Deputy Speaker of the House of Representatives as the case may be are to be final. ${ }^{11}$ Also, the Federal Constitution provides that where the Prime Minister ceases to command the confidence of the majority members of the House of Representatives, the Prime Minister shall tender the resignation of the Cabinet unless at his request, the Yang di-Pertuan Agong dissolves the Parliament. ${ }^{12}$ States' Constitutions also have similar provision. ${ }^{13}$

The questions that may arise, and have in fact arisen, from the provisions cited above is whether the court can exercise the power of judicial review in the event of violation of constitutionally provided legislative actions or rules of procedure; whether any aggrieved member of Parliament or the Legislative Assembly cannot validly challenge any irregularity in a court of law. In light of the above, the next section analyses how courts have over the years reacted to these matters which seem to be internal affairs of the legislature as part of legislative actions.

\section{THE LEGISLATIVE PROCEEDINGS AND COURTS' HANDS TIED APPROACH}

The discussion in this section attempts to examine the reactions of the courts towards reviewing internal matters of the legislature. This discussion is majorly divided as: suspension of legislative members; removal of legislative members from committees or as principal members; disqualification of legislative members; injunction to stop the proceedings of the legislature; and legislative confirmation of appointments.

$11 \quad$ See Article 56(6) and 57(6). It would appear that decisions of the House of Representatives on removal of the Speaker and Deputy Speaker of the House of Representatives as the case may be are not meant to be final as it is carefully excluded from the application of Article 57(6). However, this may still be caught by Articles 63(1) and 72(1) (for the State) for being proceedings of the legislature which is not subject to judicial review.

12 See Article 43(4) of the Federal Constitution.

13 See for instance, Article 6(3) of the Constitution of Sarawak. 


\section{Suspension of Legislative Members}

Members of the legislature are generally elected through electoral processes. The issue is whether suspension forms part of a justiciable issue in courts. This aspect seeks to analyse the justiciability of the issue of a suspension of legislative members from the House and from committees of the House.

Issues of this nature have arisen in the courts. In fact, in the case of YAB Dato' Dr Zambry bin Abd Kadir \& Ors $v$ YB Sivakumar a/l Varatharaju Naidu (Attorney General Malaysia, intervener), ${ }^{14}$

14 [2009] 4 MLJ 24. On 6 February 2009, YAB Dato’ Dr Zambry bin Abd Kadir, the first applicant, was sworn in as the Menteri Besar of Perak in place of YB Dato Seri Mohammad Nizar Jamaluddin (Nizar). The first applicant then proceeded to appoint the second to seventh applicants as his Executive Council Members (the EXCO members) and on 10 February 2009 the said applicants were accordingly sworn in as State Executive Councillors of Perak. On 11 February 2009, the Assemblyman from Taman Canning (the complainant) wrote to the Speaker of the State Legislative Assembly of Perak, the respondent, to complain that the applicants had committed acts of contempt against the State Legislative Assembly of Perak. Based on this complaint the respondent issued a summons, pursuant to Standing Order 72 of the Standing Orders of the State Assembly of Perak (Standing Order 72), to the applicants requiring them to attend before the Committee of Privileges (the committee) on 18 February 2009 to answer to a charge of breach of privileges. The breach of privileges complained of arose from alleged acts of contempt committed by the applicants; the alleged acts of contempt were that the first applicant wrongly holding himself out as Menteri Besar of Perak and acting illegally by appointing the other applicants as EXCO members and the other applicants wrongly holding themselves out as EXCO members, contrary to the provisions of the Perak Constitution while the legally appointed Menteri Besar of Perak, Nizar, and his EXCO were still in office. The applicants appeared before the committee as required and stated that they did not recognise or submit to the committee's jurisdiction. By February, the committee found the applicants guilty of the charges of contempt and suspended the first applicant from attending the sessions of the State Assembly for a period of 18 months and the other applicants for 12 months. The applicants thereafter filed an originating summons in the High Court seeking, inter alia, orders for a declaration that the decision of the 
the Federal Court of Malaysia interfered with the internal affairs of the legislative Assembly. The reason is that the Court held that applicants' challenge of their suspension from the Legislative Assembly was a matter that affected their legal status. It noted that the applicants were, therefore, entitled to seek a declaration of their legal right and that the court is empowered to ascertain whether a particular power that had been claimed had in fact been provided for. Thus, the applicants' suspensions from attending the State Legislative Assembly were declared void and therefore justiciable. $^{15}$

It is submitted that the issue of suspension goes beyond the internal affairs of the legislature as it has affected the legal right of the member concerned. ${ }^{16}$ Since the appointment of a legislature is regulated

respondent in suspending them from attending the State Legislative Assembly for a period of 18 months and 12 months respectively was against the laws of the constitution of Perak and therefore null and void. The applicants then filed a notice of motion in the Federal Court for certain questions to be answered pursuant to Article 63 of the Constitution of Perak (Article 63). These questions involved, inter alia, a consideration of whether the respondent's decision in suspending the applicants from attending the State Legislative Assembly was null and void. At the hearing the respondent raised the objection that as he had been sued in his capacity as Speaker, the action ought to have been commenced under $\mathrm{O}$. 53 of the Rules of the High Court 1980 (RHC) for judicial review. In addition, in reliance on Article 72 of the Federal Constitution (Constitution) and the Legislative Assembly (Privileges) Enactment 1959 (Enactment) of Perak, the respondent submitted that the issues raised by the appellants were not justiciable. The applicants in their reply submitted that 0.53 of the Rules of the High Court 1980 (RHC) was not applicable as there was no review of any decision and that since they were seeking to have their legal rights asserted under Section 41 of the Specific Relief Act 1950 (the Act), O. 53 was not the appropriate remedy. Ibid.

16 See generally A. O. Sambo, Judicial Review of Political Questions in Nigeria and Malaysia: A Comparative Analysis ( Unpublished Ph.D. Thesis, International Islamic University Malaysia, 2013). See also A. O. Sambo, \& Hunud Abia Kadouf, “Judicial Review of Internal Legislative Proceedings: The Nigerian Experience” in Sylvia Kierkegaard (ed.), Law \& Practice: Critical Analysis and Legal Reasoning, Denmark: IAITL, 2013, 505-519. 
by the Constitution, the removal or suspension of such members too should involve issue of constitutionality which justifies the intervention of courts. Moreover, legislators are first among equals. It is just by sheer luck that one of them becomes the Speaker or President. This, though appears to be internal affairs, has some constitutional stings which allows the court to determine its validity because the courts have power to interpret the constitution. So, the conclusion reached by the court above has justification in law. Thus, the issue of suspension of a member from the House comes within the powers of judicial review.

However, distinction must be made between where a member is suspended from the House itself and where he is suspended as a member of House committee. In the latter case, this would fall within the internal affairs of the House which the court should not ordinarily intervene. Nonetheless, procedure and due process must be followed; otherwise, the court can exercise its powers of review. However, it would appear that the court cannot interfere in this circumstance because Article 72 precludes the court from questioning the regularity or otherwise of the proceedings of the House. ${ }^{17}$ This article, even though falling within the privilege of the legislature, its effect on judicial review power on political questions is that it prohibits the courts from exercising its judicial review power on proceedings of the legislature which is essentially political in nature.

$17 \quad$ See also Article 63(1) of the Federal Constitution. The provisions of Articles 63(1) and 72(1) show that the powers of the courts in Malaysia do not extend to making pronouncements as to the validity or otherwise of the proceedings of the Parliament or even any of its Committees. Thus, where any person or group of persons seeks to challenge the validity of the proceedings of the Parliament or any of its committees, the court is required to decline jurisdiction. The provision appears similar with regards to the power of the court to entertain the actions brought for the purpose of challenging the proceedings of the Legislative Assemblies of the State. However, it appears this provision in this respect does not cover the committees of the Legislative Assemblies. This is because section 72 plainly omits 'Committees of the legislative Assembly' to make it similar to that of the Parliament. 


\section{Removal of Legislative Members from Committee or As Principal Officers}

Some members of the House are equally members of certain committees. ${ }^{18}$ Legislative members are equals. Some, however, becomes first among equals when they are elected as principal officers such as the Speaker, Deputy Speaker, House Leader and so on. This aspect seeks to examine whether the removal of members from their committees or principal members from their positions is subject to judicial review or whether they are non-justiciable being political questions.

The above issue arose in Sivakumar a/l Varatharaju Naidu $v$ Ganesan a/l Retanam. ${ }^{19}$ The main issues in this case are whether

18 See for instance Order 98 of the Standing Orders of the Nigerian Senate, 2007 as amended for list of committees. See also Regulation 73(1) for Proceeding Regulation Committee of the Malaysian Senate Standing Order. Retrieved from http://www.parlimen.gov.my/ pages.php?view=67\&uweb=dn\&lang=en accessed on $9^{\text {th }}$ August, 2012. [2010] 7 MLJ 355.The facts of the case are that following the 12th General Elections, the political alliance of Pakatan Rakyat formed the Perak State Government and the plaintiff was elected by the Perak Legislative Assembly (Assembly) as its Speaker. In February 2009, the political alliance of Barisan Nasional formed the new state government replacing the political alliance of Pakatan Rakyat. On 23 April 2009, the office of the Secretary to the Assembly received two motions for the removal of the plaintiff as Speaker and for appointment of the defendant as the Speaker. On 7 May 2009, the Assembly convened for the first time since the formation of the new state government and the plaintiff was forcibly ejected from his seat at the Assembly hall. Subsequent to the proceedings of the Assembly on 7 May 2009, the plaintiff filed the present action. The plaintiff asserted that the defendant's unknown servants and/or agents had attacked him. The plaintiff claimed, inter alia, damages and an injunction to prevent the defendant and/or his agents or servants from denying the plaintiff entry to the Assembly and/or prohibiting the plaintiff in whatsoever way from occupying the office and carrying out his duties as the lawful Speaker. The defendant applied to strike out the action under O. 18 r. 19 of the Rules of the High Court 1980 on the grounds that the plaintiff's pleading was scandalous, frivolous and vexatious and that it was an abuse of the process of the court. 
proceedings in the Legislative Assembly are generally and in particular whether the appointment and removal of State Assembly Speaker is justiciable. ${ }^{20}$ The Court, while dismissing the plaintiff's case in this matter, held inter alia that the Assembly was properly convened on 7 May 2009 and that the sitting on that day was lawful. It noted that the removal of the plaintiff and the appointment of the defendant as the new Speaker were part of the proceeding of the Assembly on 7 May 2009. Pursuant to Article 36A of the State Constitution of Perak, ${ }^{21}$ the Assembly has the power or jurisdiction to elect and/or to dismiss the Speaker and that the issue of who was the validly appointed Speaker was not within the court's jurisdiction. It further noted that the validity of any proceeding in the Assembly is not justiciable and that Article 72(1) of the Federal Constitution prevents the court from examining the matters that took place in the course of the proceedings of the Assembly on 7 May 2009. ${ }^{22}$ The Court noted that whatever matter relating to the removal and the appointment of the Speaker ought to be examined, discussed and resolved in the Legislative Assembly which has exclusive jurisdiction over the

$20 \quad$ The Court considered Article 72 of the Federal Constitution because the Article makes provision in respect of State Assemblies. It provides that: "The validity of any proceedings in the Legislative Assembly of any State shall not be questioned in any court." This is also in line with Article 44 (1) of the Constitution of the State of Perak. Article 36A (6) provides that: "where any question arises regarding the disqualification of the Speaker under Clause 5 the decision of the Legislative Assembly shall be taken and shall be final." Removal of the Speaker is part of the instances where he is regarded to be disqualified. Apart from Perak, many other States Constitutions have similar provisions. See Article 54(6) of the Constitution of the State of Kedah; Article 45(6) of the Constitution of the State of Kelantan; Article 20(6) Constitution of the State of Malacca; Article 57 of the Constitution of the State of Negeri Sembilan; Article 27(6) of the Constitution of the State of Pahang; Article 20(6) of the Constitution of the State of Penang; Article 56(5) Constitution of the State of Perlis; Article 71(3B) of the Constitution of the State of Selangor.

22 Azahar Mohamed J. in his judgement was of the view that Article 72(1) of the Federal Constitution prevents the court from examining the matters that took in the course of the proceedings of the Legislative Assembly on 7 May 2009 given that the Legislative Assembly has the power or jurisdiction to elect and/or to dismiss the Speaker. 
matter and it has the absolute right to control its own proceedings. In the opinion of the Court, the decision of the Legislative Assembly on 7 May 2009 to remove the plaintiff as the Speaker and to appoint the defendant as the new Speaker is conclusive. The matter has been determined by the Legislative Assembly on 7 May 2009. To question the validity of the removal of the plaintiff as the Speaker and the appointment of the defendant as the Speaker is to question the validity of the proceeding of the Assembly. ${ }^{23}$ An appeal to the Court of Appeal was also dismissed on similar grounds of non justiciability of issues of political nature having regard to Article 72 of the Federal Constitution. ${ }^{24}$

Thus, the law in the courts' views is that removal of Speaker as the Speaker of the House is a non-justiciable matter. The regularity or otherwise of the procedure and proceeding leading to same is not the business of the court as Articles 63 (1) and 72 (1) of the Federal Constitution precludes the courts' intervention in this regard. Apart from these provisions, many States Constitutions have similar provisions, as earlier noted, which do not give room for courts' interventions in the removal of the Speaker as it renders the decisions of the House as final.

\section{Disqualification of Legislative Members}

The issue of disqualification of members of the legislature may be preelection or post-election. ${ }^{25}$ This part of the discussion focuses on post-

$23 \quad$ Although the matter had to do with State Assembly which needs to be governed by the State Constitution, Article 72 was relied on because the provision had to do with States.

$24 \quad$ See Sivakumar a/l Varatharaju Naidu v Ganesan a/l Retanam [2011] 6 MLJ 70 for the decision of the Court of Appeal.

25 Where the matter has to do with pre-election disqualification, it is clearly within the jurisdiction of the High Court to decide (See Article 118 of the Federal Constitution). The court can exercise its power of review where a person is disqualified prior to the election. Thus, where the disqualification prior to election is established, the court has the power to declare such election or appointment of the member of the legislature null and void (See the combined effect of Articles 49 and 50 of the Federal Constitution. See also the case of Fan Yew Teng $v$ Setia Usaha, Dewan Ra'ayat \& Ors. [1975] 2 MLJ 40). Thus, while Article 48 
election disqualification. The issue whether a member of Parliament, being disqualified as a parliamentarian having been convicted of the offence of sedition, arose in the case of Fan Yew Teng $v$ Government of Malaysia. ${ }^{26}$ Chang Min Tat J. held that the Court could not interfere with the right of the House to decide on disqualification of members of Parliament. The Court also noted that it could not interfere with the corresponding right of the House pursuant to the proviso to Article 53 to decide to postpone taking a decision in order to allow for the appeal to be heard or for the plaintiff to make an application for pardon. The Court

(1) governs pre-election disqualification, Articles 50 (1) and 53 relates to post-election disqualification.

[1976] 2 MLJ 262. The facts of this case show that the plaintiff, a member of Parliament, was convicted for sedition and was fined RM2,000. Deputy Minister of Co-ordination of Public Corporations on 31 October 1975 presented a motion in the Dewan Ra'ayat (House of Representatives) that because of the conviction and sentence, the plaintiff had become disqualified for membership of the house. The motion was passed on 4 November 1975, and the matter was referred to the Committee of Privileges of the Dewan Ra'ayat. The plaintiff then sued for declaration: (1) that no question under Article 53 of the Federal Constitution as to the plaintiff's disqualification for membership of the Dewan Ra'ayat has arisen by the plaintiff's mere conviction and fine of \$2,000 in default six months' imprisonment on 13 January 1975, (vide Selangor Criminal Trial No. 4 of 1974) on a charge under Section 4(1) (c) of the Sedition Act (Revised 1969); (2) that the plaintiff has a constitutional right to exhaust his legal right of appeal to the Judicial Committee of the Privy Council and thereafter, if unsuccessful, to apply to His Majesty the Yang di-Pertuan Agong for a free pardon before any question as to his disqualification can arise under Article 53 of the Federal Constitution; (3) that the Dewan Ra'ayat can only take a decision on the plaintiff's disqualification after he has exhausted his legal right to appeal to the Judicial Committee of the Privy Council and has thereafter unsuccessfully exercised his right to apply to His Majesty the Yang Di-Pertuan Agong for a free pardon; (4) that the plaintiff's pending appeal to the Judicial Committee of the Privy Council has rendered the matter sub-judice; (5) that under Article 53 of the Federal Constitution, it is the Dewan Ra'ayat alone and no other authority or body which can go into the question relating to the plaintiff's disqualification as a member of the Dewan Ra'ayat. 
was of the opinion that the reliefs sought by the plaintiff were outside the jurisdiction of court.

In the similar case of Lim Cho Hock v Speaker, Perak State Legislative Assembly, ${ }^{27}$ the Court held that the Legislative Assembly is the final arbiter in any question arising as to whether a member of the Legislative Assembly has become disqualified from membership. The matters raised were held to be for the Legislative Assembly to decide and within its exclusive jurisdiction and not for the courts to determine. However, in the case of Fan Yew Teng $v$ Setia Usaha, Dewan Ra'ayat $\&$ Ors. ${ }^{28}$ the Court exercised its review power of what was ordinarily supposed to be matters within the affairs of the House of Representatives. ${ }^{29}$ The Court held that the seat of the plaintiff was not

27 [1979] 2 MLJ 85 In this case, the applicant applied by originating summons for the determination of the question whether the seat of a member of the Legislative Assembly, who was also the Speaker, had been vacated as he had not taken the oath required of a member. The respondent applied to set aside the Originating Summons on the grounds inter alia that the application was not maintainable in law and procedure and that the court had no jurisdiction to entertain the application as the reliefs sought were exclusively within the jurisdiction of the Legislative Assembly of the State of Perak.

$28 \quad$ [1975] 2 MLJ 40.

29

The facts of the case as stated by Mohamed Azmi J. are that: "the plaintiff, Mr. Fan Yew Teng, was returned as a Member of Parliament for the Parliamentary Constituency of Menglembu in the General Election held in August 1974. On January 13, 1975 he was convicted in the High Court at Kuala Lumpur and sentenced to a fine of \$2,000 or six months imprisonment for an offence under Section 4(1)(c) of the Sedition Act (Revised 1969). On the same day, he appealed against the said decision and the appeal is now pending in the Federal Court. By letter dated February 4, 1975 he was informed by the Setia Usaha. Dewan Ra'ayat (first defendant) presumably acting on the direction of the Speaker, that on his conviction and sentence aforesaid he had become disqualified under Article 48(1) (e) of the Federal Constitution and by virtue of Article 50(1) his seat had become vacant. By writ of election dated February 17, 1975, the Secretary to the Election Commission directed the Returning Officer for the Parliamentary Constituency of Menglembu to proceed with the bye-election of the said constituency. The required notice under regulation 3(1) of the Elections (Conduct of Elections) Regulations. 1959 was published in the February 20, issue of Utusan Malaysia newspaper.” Ibid. 
vacant simply because he was convicted by the High Court. He has the right to exhaust his legal rights. Consequently, it was further held that Election Commission and the Returning Officer for the Parliamentary Constituency of Menglembu could not legally hold a by-election for the Parliamentary Constituency of Menglembu because there was no vacancy of seat in the constituency.

It is observed that after these decisions, the Federal Constitution was amended. ${ }^{30}$ A proviso was added to the finality of the decision of the House as to disqualification under Article 53(1) so as to exclude inter alia "any proceedings that may affect the decision (including for the removal of the disqualification)." 31 It is submitted that the new proviso allows the exercise of judicial review power on such decisions of the House as to disqualification. Also, many States in Malaysia have reflected this amendment in the State Constitutions. ${ }^{32}$

In the more recent decision of Dato' Abu Hasan bin Sarif $v$ Dato' Dr. Abd. Isa bin Ismail, ${ }^{33}$ an issue of this nature came up for consideration. The facts of the case show that on 17 August, 2009, the respondent as the speaker of the Legislative Assembly of the State of Kedah (the speaker) informed the Election Commission of Malaysia (EC) that the Kota Siputeh (N3) seat in the State of Kedah had purportedly

30 See Constitution (Amendment) Act 1988, Act A704. It came into force on $10^{\text {th }}$ June, 1988.

31 See the combined effects of Articles 48 and 53(1) and (2) of the Federal Constitution.

32 See Article 33 of the Constitution of the State of Perak; Article 22 (1) and (2) of the Constitution of the State of Johore; Article 18(1) and (2) of the Constitution of the State of Malacca; Artticle 55 (1) and (2) of the Constitution of the State of Negeri Sembilan; Article 25 (1) and (2) of the Constitution of the State of Pahang; Article 18(1) and (2) of the Constitution of the State of Penang; Article 54 of the Constitution of the State of Perlis; Article 19(1) and (2) of the Constitution of the State of Sabah; Article 19(1) and (2) of the Constitution of the State of Sarawak; Article 67(1) and (2) of the Constitution of the State of Selangor. However, some States seems to retain the position of finality of the House decision in this regard. See Article 29A of the Constitution of the State of Trengganu; Article 52 of the Constitution of the State of Kedah and Article 32 of the Constitution of the State of Kelantan. [2012] MLJU 11. 
become vacant because the applicant did not attend the State Assembly on purportedly two consecutive meetings of the State Assembly, namely on 1 April, 2009 and 9 August, 2009. But, the EC on 1 September, 2009 decided that the Kota Siputeh (N3) seat had not become vacant. The respondent filed an application for judicial review to, inter alia, seek a declaration that the applicant was no longer the State Assemblyman for Kota Siputeh (N3) and that the applicant's seat was vacant, as well as a certiorari to quash the EC's decision. The High Court granted the declarations and the order for certiorari sought by the respondent. This meant that the applicant was no longer the State Assemblyman of Kota Siputeh and his seat was declared vacant. The applicant appealed the decision of the High Court to the Court of Appeal. The EC also filed a separate appeal to the Court of Appeal against the decision of the High Court. The Court of Appeal allowed the applicant's appeal and set aside the High Court's decision and restored the applicant as the State Assemblyman of Kota Siputeh (N3) constituency. The respondent applied for leave to appeal to the Federal Court against the decision of the Court of Appeal. The respondent also applied to the Court of Appeal for a stay of the Court of Appeal's decision pending the disposal of the application of leave to appeal to the Federal Court. The Court of Appeal granted the respondent's application for a stay of the Court of Appeal's decision. The Federal Court vacated the Court of Appeal's order for stay of decision and reinstalled the disqualified State Assemblyman of Kota Siputeh (N3) thereby reviewing the decision of the Legislative Assembly.

It is submitted that the issue of membership disqualification discussed above relates to post-election disqualification. Post elections disqualifications are left for the House to decide, but the member must be allowed to exhaust his legal rights to appeal and to ask for pardon where it is disqualification with respect to conviction.

So, the initial attitude of the courts was to consistently decide not to review the decision of the legislature on the issue of post-election disqualification. The courts saw it as a matter which fell within the powers of the legislature which they are not prepared to entertain. The current position seems to be that the court can exercise judicial review power where the validity of the proceedings leading to such disqualification is in issue. Similarly, the Court shall also admit judicial review power where the matter has to do with pre-election disqualification. 


\section{Injunction to Stop Proceedings of the Legislature}

An injunction is a restraining order given by the court prohibiting the doing of an act. The issue here is whether an injunction will lie to halt the proceeding of the legislature. In a situation where the court is called upon to grant an injunction against the proceeding of the legislature, what are the courts' reactions to this? In the case of Tun Datu Haji Mustapha Bin Datu Harun $v$ Legislative Assembly of State of Sabah \& Ors, ${ }^{34}$ the question before the court was whether the court could question the validity of the proceedings of the Assembly that was about to commence and issue an injunction to stop it. In relation to Sabah, the court noted that Article 25 of the State Constitution provides that subject to Article 72 of the Federal Constitution the Assembly may regulate its privileges, immunities or powers but they should not exceed those of Federal Parliament. Thus, Article 72(1) of the Federal Constitution provides that the validity of any proceedings in the Legislative Assembly of any State shall not be questioned in any court. The Court, therefore, declined jurisdiction in this case. ${ }^{35}$

It needs to be pointed out that based on the doctrine of separation of powers the courts should not ordinarily grant an injunction to stop the proceeding of the legislature more so when it is for law making process. This is because doing this will directly interfere with the affairs of the legislature. It can be said that the proceedings of the legislature involves some high political undertones that are tactical, capricious and slippery and that the court should wait until the act is done before intervening.

[1986] 2 MLJ 388. The facts of the case are that the plaintiff applied for an interlocutory injunction to restrain the Legislative Assembly of Sabah from sitting because he claimed the Yang di-Pertua Negeri had exercised his powers of summoning the sitting following the advice of a person or cabinet which the plaintiff said had not been validly appointed and that at that sitting the defendants will carry out acts which they are not legally authorised to do.

35 See also S.A. de Smith in his "Judicial Review of Administrative Action" 3rd edn, at 418 where the learned author says the courts have no jurisdiction to restrain by injunction, or otherwise to pass upon, any conduct that forms part of proceedings in Parliament, even though the matter in issue is not directly connected with the process of legislation. 
This may also lead to collision course with legislative members. So, the courts have restrained themselves from granting an injunction to stop legislative proceedings in line with Article 62 and 72 of the Federal Constitution.

\section{Proceedings on Motion of No Confidence}

Proceedings on motion of no confidence is another important area or instance where the validity of the proceedings of the legislature may become an issue before the courts. This is because the process of a no confidence motion involves what the Constitution has committed to the legislature for determination. In other words, issues having to do with motion of no confidence are within the main domain of the legislature as provided for under the Constitution. This aspect is slightly different from the general proceedings of the legislature in that while the general proceedings is usually guided by the rules of the legislature made pursuant to the powers conferred on it by the Constitution, the procedure relating to motion of no confidence on the executive is regulated directly by the Constitution itself. Also, while the internal affairs of the House merely, in many cases, affect the members of the House, motion of no confidence proceedings affects the third party, the executive arm of government.

The issue of legislative loss of command of confidence is worth examining. In view of this, questions may arise as to whether the court can interfere with the process of declaring loss of confidence by the legislature. There is a procedure, as will be shortly shown, for the declaration of such loss of confidence. In a situation where the procedure is not followed, questions may arise as to whether that can be regarded as a ground for the exercise of judicial review power or whether it is a non-justiciable issue. Again, where a loss of confidence is declared and the person against whom it is declared refuses to resign, can the court interfere in the circumstance?

When the issue arose, the Malaysian Court referred to Adegbenro, a Nigerian case. Before analysing the cases, it is important to state that the law is that where the Prime Minister no longer enjoys the confidence of the support of the majority members of the House of Representatives, unless at his request, the Yang di-Pertuan Agong dissolves the Parliament, 
the Prime Minister must tender his resignation and of the Cabinet. ${ }^{36}$ The option open to the Prime Minister is to either request the Yang di-Pertuan Agong to dissolve the Parliament where he no longer commands the support of the majority of the House of Representatives though subject to the acceptance of the Yang di-Pertuan Agong. ${ }^{37}$ The States Constitution also has similar provision regarding the loss of confidence in the Menteri Besar by the Legislative Assembly. ${ }^{38}$

The first opportunity of the court to pronounce on this issue came in the case of Stephen Kalong Ningkon $v$ Tun Abang Haji Openg and Tawi Sli. ${ }^{39}$ The Court exercised judicial review power by holding

$36 \quad$ See Article 43(4) of the Federal Constitution. See Khairil Azmin Mokhtar, “The Emergency Powers (Kelantan) Act 1977” in Andrew Harding and H.P. Lee (eds.), Constitutional Landmarks in Malaysia: The First 50 Years 1957- 2007, Malayan Law Journal Sdn Bhd, Malaysia, 2007, at 138.

37 The Yang di-Pertuan Agong has the discretion on whether to give or to refuse consent for the purpose of dissolving the Parliament. See also Article 43 (4) and Article 40 (2) (b) of the Federal Constitution.

$38 \quad$ See for instance Article XVI (6) of the Perak State Constitution provides that if the Menteri Besar ceases to command the confidence of the majority of the members of the Legislative Assembly then, unless at his request His Royal dissolves the Legislative Assembly, he shall tender the resignation of the Executive Council.

$39 \quad[1966] 2$ MLJ 187. The facts of the case are that: On the $16^{\text {th }}$ June 1966, the Governor of Sarawak (the first defendant) received a letter signed by 21 members of the Council Negri to the effect that the writers had no longer any confidence in the plaintiff, their Chief Minister. The Governor thereupon wrote and informed the plaintiff on the $16^{\text {th }}$ June that from representations he had received he was satisfied that the plaintiff had ceased to command the confidence of the Council Negri and invited the plaintiff to resign. The plaintiff in his reply of the $17^{\text {th }}$ June informed the Governor that the Governor's views as to the loss of confidence of the members of the Council Negri in the plaintiff was not supported by the meeting of the Council Negri held on the $14^{\text {th }}$ June and the plaintiff in the same letter requested that he be supplied with the names of the persons who had signed the representations. In reply to this letter the Governor in his letter of the same date informed the plaintiff that as the plaintiff had refused to tender the resignation of members of the Supreme Council in accordance with Article 7(1) of the Constitution of the State of Sarawak (although the plaintiff had ceased to have the confidence 
that Article 6(3) of the Constitution of Sarawak restricted the power of the Governor of Sarawak in appointing as Chief Minister a member of the Council of Negri (State Council) who in his judgment was likely to command the confidence of the Council of Negri. In the Court's view, by Section 21 of the Interpretation Ordinance, it is only when the Council of Negri had shown lack of confidence could the Governor's power to dismiss, if it exists, be exercised. The Court noted that under the provisions of the Sarawak Constitution, lack of confidence may be shown only by a vote in the Council Negri. The Court further held that if the Constitution of Sarawak could be interpreted as granting the Governor a power to dismiss the Chief Minister when he had refused to resign and failed to request dissolution but in this case the plaintiff was never given a reasonable opportunity to tender his resignation or to request dissolution. Consequently, the Court held that the purported dismissal of the plaintiff by the Governor was ultra vires null and void.

The Court appears to follow the reasoning of the Federal Supreme Court in Adegbenro's case but declined clearly from following the decision of the Privy Council in that case because of the following distinguishing features and circumstances as noted by the Court:

(1) In the Nigerian case it was mathematically beyond question that more than half the House no longer supported

of a majority of the members of the Council Negri) he declared that the plaintiff and other members of the Supreme Council had ceased to hold office and appointed the second defendant as Chief Minister forthwith. The Governor also forwarded a list of the names of persons who had signed the representations as requested by the plaintiff. The plaintiff thereupon commenced proceedings against the Governor and the second defendant claiming the following reliefs: (a) a declaration that the Governor acted unconstitutionally when he declared on the $17^{\text {th }}$ June that the plaintiff had ceased to hold the office of Chief Minister; (b) a declaration that the Governor should not have relieved the plaintiff from the office of Chief Minister on the ground of alleged loss of confidence in the plaintiff as Chief Minister; (c) a declaration that the purported dismissal of the plaintiff by the Governor was ultra vires, null and void; (d) a declaration that the plaintiff is and has been at all material times the Chief Minister of Sarawak and (e) an injunction restraining the second defendant from acting as Chief Minister. 
the Premier. (2) The measurement in Nigeria was a measurement of "support," not of "confidence." The Sarawak Constitution is dated subsequent to the decision of Adegbenro v. Akintola, and it does seem to me that the "confidence" of a majority of members, being a term of art, may imply reference to a vote such as a vote of confidence or a vote on a major issue. (3) In Nigeria it was not disputed that the Governor had express power to remove the Premier from office if he no longer commanded support. (4) In Nigeria the Governor had express power to assess the situation "as it appeared to him.” (5) In Nigeria all Ministers, including the Premier, held office "during the Governor's pleasure;" although there was an important proviso to this.

In Tun Datuk Haji Mohamed Adnan Robert v Tun Datu Haji Mustapha Bin Datu Harun; Datuk Joseph Pairin Kitingan v Tun Datu Haji Mustapha Bin Datu Harun, ${ }^{40}$ the Supreme Court of Malaysia decided a matter relating to the power of the legislature to decide who commanded its confidence. The Court noted that questions pertaining to whether the Head of States had exercised his discretion properly, lawfully and constitutionally or what factors he puts into consideration in deciding whether or not to appoint or remove the Chief Minister were non-justiciable political questions because the powers are discretionary in nature. However, the Court observes that the mere fact that a person seeks to protect a political right does not mean that it presents a political question. Whether an issue raises a political question; whether it has been given by the Constitution to another branch of

40 [1987] 1 MLJ 471. The Court further held that the issues here are the matter of the initial appointment of the respondent as Chief Minister, the subsequent purported revocation of that appointment and the consequential appointment of the $2^{\text {nd }}$ appellant as Chief Minister by the 1st appellant. The Court agreed that the learned judge has dealt somewhat exhaustively with all the contentions raised on behalf of the appellants on the question of jurisdiction and agree with the reasons he has given and his conclusion that the matters raised in the respondent's action are justiciable and not without the jurisdiction of the court for trial. 
government is itself an issue for judicial determination. The reason, as noted by the Court, is that "the Constitution has made the courts the ultimate interpreter of the Constitution. The courts accordingly cannot reject a bona fide controversy as to whether some action denominated 'political' exceeds constitutional authority." The Court finally exercised its judicial power of review by holding that justiciable issues did arise in this case for judicial determination and that the Court had jurisdiction to determine the controversial matter in this case. The reason in the courts' opinion is that "motions of confidence or no confidence or whatever passed in the Legislative Assembly might be political ratification or rejection of the choice made but cannot affect the primary issues of the appointment and revocation which are legal and justiciable questions clearly within the competence of judicial consideration and determination.”

The Court in Datuk (Datu) Amir Kahar bin Tun Datu Haji Mustapha $v$ Tun Mohd Said bin Keruak Yang Di-Pertua Negeri Sabah \& Ors. ${ }^{41}$ was of the view that to show that a Chief Minister

41 [1995] 1 MLJ 169; [1995] 1 CLJ 184. The facts of the case are that "Following the Sabah state elections on 18 and 19 February 1994, Datuk Joseph Pairin Kitingan (Datuk Pairin) was appointed Chief Minister of Sabah. On the advice of Datuk Pairin, other elected members from his party, including the plaintiff, were appointed to form the State Cabinet on 21 February 1994. Subsequent to defections by three members of the State Legislative Assembly (the Assembly) from his party to the opposition, Datuk Pairin requested the Yang di-Pertua Negeri, the first defendant, to dissolve the Assembly but the first defendant withheld his consent. Datuk Pairin later tendered his resignation as Chief Minister of Sabah on 17 March 1994. He, however, did not tender the resignation of the other members of his Cabinet. On the same day, the first defendant appointed the second defendant as the new Chief Minister to replace Datuk Pairin. On 24 March 1994, the first defendant, on the advice of the second defendant, appointed the third to ninth defendants as the other members of the Cabinet of the second defendant. The plaintiff sought a declaration that since no motion of no confidence was ever tabled in the Assembly against Datuk Pairin, his resignation was personal to him and did not affect the appointment of the plaintiff as a Deputy Chief Minister and Minister of Agriculture and Fisheries. The plaintiff also sought a declaration that the first defendant had acted ultra vires the provisions of the Sabah State Constitution (the Constitution) by purportedly appointing the third to ninth defendants 
ceases to command the confidence of a majority of the members of the Assembly for purposes of Article 7(1) of the Sabah Constitution, it may not depend upon the actual motion to be tabled in the State Legislative Assembly. It may be available from 'extraneous circumstances' from the Legislative Assembly depending on the circumstances of each case. In this case, based on the circumstances presented to it, the court was satisfied that the resignation of Datuk Pairin as the Chief Minister on 17 March 1994 was a resignation pursuant to him ceasing to command such a confidence. Judicial review power was thus denied.

The issues before the Court of Appeal in Dato' Dr Zambry bin Abd Kadir v Dato' Seri Ir Hj Mohammad Nizar bin Jamaluddin (Attorney General of Malaysia, intervener) ${ }^{42}$ inter alia included loss

as members of the Cabinet when at all material times the appointments of the plaintiff and the other Cabinet members had not been revoked nor had they resigned." Application was dismissed.

42 [2009] 5 MLJ 464. The facts of the case are that at the conclusion of the 12th General Election, the political alliance of Pakatan Rakyat (comprising members of PKR, PAS and DAP) won 31 seats for the Perak State Legislative Assembly (PSLA). The other 28 seats were won by the Barisan Nasional (BN). Thus, Pakatan Rakyat formed the state government with Nizar as the Menteri Besar (MB). Several months later, the Speaker of the Perak Legislative Assembly (Speaker) claimed that the Behrang and Changkat Jering assemblymen from PKR and Jelapang assemblywoman from DAP (the three assemblypersons) had by separate letters addressed to the Speaker, tendered their resignation as members of the PSLA. The Speaker then purported to accept their resignation and declared the respective seats vacant. However, the three assemblypersons separately sent letters to the DYMM Sultan of Perak (Sultan) claiming, inter alia: (1) that they did not issue any letter of resignation and that they were still serving as assemblypersons; (2) that they had lost their confidence in Nizar as the MB; and (3) that they were leaving their respective political parties and were now supporting the BN. The Election Commission refused to establish a 'casual vacancy' for the three state seats in question. In light of these developments, Nizar had an audience with the Sultan where he made a request to dissolve the PSLA. Meanwhile, Dato' Seri Najib in his capacity as the Chairman of the Perak BN had an audience with the Sultan where he presented letters of support with signatures from 28 members of $\mathrm{BN}$ and from the three assemblypersons stating that they 
of confidence by majority of members of Legislative Assembly towards the previous Menteri Besar (Nizar), and the validity of his dismissal on ceasing to command confidence of majority members of State Legislative Assembly and whether motion of no confidence is required to dismiss the Menteri Besar. The issue here was that Nizar filed an application for judicial review pursuant to Or 53 of the Rules of the High Court 1980 claiming, inter alia: (1) that he continued to hold office of the Menteri Besar since no motion of confidence had been tabled against him in the Perak State Legislative Assembly (PSLA); (2) that since there was no dissolution of the PSLA, the Sultan was not entitled to declare the position of Menteri Besar vacant pursuant to Article XVI (6) of the Perak State Constitution especially since his request for dissolution was made under Article XXXVI; and (3) that only the PSLA could decide his fate as the Menteri Besar by a vote of no confidence. The High Court judge allowed Nizar's application for judicial review and hence there was an appeal.

The Court of Appeal held inter alia while allowing the appeal that by virtue of Article XVI (6), it was not mandatory that there must be a motion of no confidence passed in the PSLA against a Menteri Besar before he ceases to command the confidence of the majority of the members. The fact that a Menteri Besar ceases to command the confidence of the majority of the members of the PSLA can be established by other means. It cannot be solely confined to the vote taken in the PSLA. The Court noted that the circumstances clearly showed that on $5^{\text {th }}$ February 2009, Nizar no longer had the confidence of the majority of the members of the PSLA. ${ }^{43}$ The Court further held that Article XVI (6) requires the Menteri Besar to tender the resignation of the executive council and of himself if he ceases to command the confidence of the majority of the members of the PSLA stating that the word 'shall' in Article XVI (6) must be interpreted as being 'mandatory.' ${ }^{44}$ The Court

would support a BN candidate as the new MB. These 31 members also declared their support for BN in an audience before the Sultan. The Sultan therefore rejected the request for the dissolution of the PSLA and asked Nizar to tender the resignation of the Executive Council including himself. The Sultan then in accordance with art XVI (2) of the Perak Constitution, appointed Zambry as the MB of Perak.

$43 \quad$ See paras $26 \& 32$.

44 (Per Raus Sharif JCA). See paras 43-44 see also paras 11-12. 
further ruled that the withholding of consent to a request for the resolution of Parliament or the Legislative Assembly is a Royal Prerogative and is not justiciable. Hence, judicial review was denied.

It should be observed that the courts in Malaysia have refused judicial review in matters relating to motion of no confidence. The only case where the mode of determining the motion of no confidence was questioned was Stephen Kalong's and Adnan's cases. Other courts' decisions have favoured the decision of the Privy Council in Adegbenro's case that motion need not be tabled on the floor of the House as there are other ways, ${ }^{45}$ in which it could be shown that Prime Minister or Chief Minister as the case may be ceases to command the confidence of the majority of the members.

\section{Expediency in the Exercise of Legislative Actions}

The word expediency here is used to refer to the aptness, motive or reasonableness of the legislative actions. The issue is whether the court has the power to review the motive of the legislature in the exercise of its powers. The legislature usually has certain motives in mind when exercising its legislative powers. The motive can be for social, economic, political and sometimes selfish reasons. The motive may sometimes be bad where the circumstances of the matter show clear evidence of bad faith or mala fide in the exercise of such powers. In all these, does the court have the power to review the action of the legislature on the grounds that the motive behind the exercise of such powers is bad or unreasonable? This issue arose in Loh Kooi Choon $v$ The Government of Malaya. ${ }^{46}$ In this case, the court refused to exercise judicial review power of an Act on the ground of being harsh or causes any injustice as it held that the courts ought not to enter this political thicket, even in such a worthwhile cause as the fundamental rights guaranteed by the Constitution. The basis for this conclusion of the court was that it would encroach into the powers and functions of the legislature. The Court was, therefore, of the

$45 \quad$ For instance, collecting signatures of members to show loss of confidence. This also shows that there are no limited means or material the the Governor can use to come to such conclusion.

46 [1977] 2 MLJ 187. 
view these issues are better left for the legislature to decide and not the court. Raja Azlan Shah FJ (as he then was), speaking for the Federal Court, was of the opinion that the question whether the impugned Act is "harsh and unjust" is a question of policy to be debated and decided by Parliament, and therefore not meant for judicial determination. To sustain it would cut very deeply into the very being of Parliament being political in nature.

However, this position seems to have changed with the case of Dewan Undangan Negeri Kelantan \& Anor v Nordin Bin Salleh \& Anor. ${ }^{47}$ The Supreme Court reviewing the reason for amending Article XXXIA of the Kelantan State Constitution was of the view that if the phrase 'for any reasons whatsoever' stated in the impugned Article XXXIA of the Kelantan State Constitution is meant to include resignation of membership of a political party, then, that part of the Article XXXIA is also inconsistent with the provision of Article 10(1) (c) of the Federal Constitution and is void by virtue of Article 4(1) of the Federal Constitution. The Court reasoned that Article XXXIA makes illusory the fundamental right of association of the plaintiffs. This was because the grounds for such restrictions are already stated in the Article 10(2) (c) and (3) of the Federal Constitution. ${ }^{48}$

[1992] 1 MLJ 697. The facts of the case are that: on $3^{\text {rd }}$ July 1991 the first defendant passed a resolution pursuant to the impugned legislation that the first and second plaintiffs had ceased to be members of the Dewan Undangan Negeri Kelantan and declared the seats for the constituencies of Sungai Pinang and Limbongan vacant. By reason of the vacancies the Election Commission of Malaysia (the third defendant) took steps to hold by-elections in the aforesaid constituencies and the by-elections were held and completed on 26 August 1991. In the by-elections, the plaintiffs stood for election as candidates for the Barisan Nasional but lost. The plaintiffs sought an order declaring that Article XXXIA of the Kelantan State Constitution is invalid, null and void as it is ultra vires the provisions of Article 10(1) (c) of the Federal Constitution. The plaintiffs contend that the new Article XXXIA of the Kelantan State Constitution is inconsistent with the provisions of Article 10(1) (c) of the Federal Constitution and is therefore void under Article 4(1) of the Federal Constitution.

48 The grounds for such restriction are the interest of the security of the Federation or any part thereof, public order or morality. 
In another case, the Court has found a lee way for making necessary incursion into what seems to be the motive behind legislation. Thus, in Sivarasa Rasiah v Badan Peguam Malaysia \& Anor, ${ }^{49}$ Federal Court held that although the Article uses the word 'restrictions,' the word 'reasonable' should be read into the provision to qualify the width of the proviso so that it would read 'such reasonable restrictions. ${ }^{50}$ The Court further cited with approval the similar reasoning of the Court of Appeal in Dr Mohd Nasir bin Hashim $v$ Menteri Dalam Negeri Malaysia. ${ }^{51}$ This shows that when the State Legislature relies on one or more of the provisions of Article 10(2) to justify a statute, the Court would determine whether the restriction that the impugned statute imposes is reasonably necessary and expedient for one or more of the purposes specified in that article. If it is not reasonable, the court would nullify it. Thus, importing the word reasonableness gives more room for judicial review on legislative actions.

49 [2010] 2 MLJ 333. The facts are, the appellant, an advocate and solicitor, who is also an office bearer of a political party and a Member of Parliament wishes to stand for and, if elected, serve on the Bar Council which is the governing body of the Malaysian Bar. Section 46A (1) of the Legal Profession Act 1976 (the Act) prohibits him from doing so. It provides: “A person shall be disqualified for being a member of the Bar Council or a Bar Committee or of any committee of the Bar Council or a Bar Committee: b) if he is a member of either House of Parliament, or of a State Legislative Assembly, or of any local authority; or c) if he holds any office in: (i)any trade union; or (ii) any political party.” The appellant challenged the constitutionality of Section 46A (1) up to the Federal Court based on three broad grounds. First, that the section violates his rights of equality and equal protection guaranteed by Article 8(1) of the Constitution. Second, that it violates his right of association guaranteed by art 10(1) (c). Third, that it violates his right to personal liberty guaranteed by Article 5(1). He argues that in the event that any one of these rights is found to be violated, the section must be declared void as being inconsistent with the supreme law. At p. 340.

51 [2006] 6 MLJ 213; [2007] 1 CLJ 19. The Court reasoned that the restrictions which Article 10(2) empowers the Parliament to impose must be reasonable restrictions. In other words, the word 'reasonable' must be read into the sub-clauses of Article 10(1) (see para 9). 
More recently, the Court of Appeal in Muhammad Hilman Bin Idham \& Ors $v$ Kerajaan Malaysia \& Ors.$^{52}$ followed the principle enunciated in Sivarasa's case above when it held that it is now settled law that Parliament can no longer impose a restriction on freedom of speech, in any manner it deems fit, for the purpose of protecting the interests spelt out in Clause 2(a) of Article 10. Any restriction imposed on freedom of speech by Parliament must be a reasonable restriction, and the Court, if called upon to rule (such as in the present case), has the power to examine whether the restriction so imposed is reasonable or otherwise (besides determining as to whether or not the restriction falls within the exceptions as spelt out by Clause (2) (a) of Article 10); and in the event it were to hold that the restriction is unreasonable - to declare the impugned law imposing the restriction as being unconstitutional and accordingly null and void. This is a remarkable departure from the position taken by the Federal Court years ago in Loh Kooi Choon v. Government of Malaysia. ${ }^{53}$ In that case, the Federal Court was urged to adopt the doctrine, but the Court then refused to do so. Consequently, section 15(5) (a) of the Universities and University Colleges Act 1971 (UUCA) which restricts the University Students from expressing support or sympathy for the opposition from any political party contravenes article 10(1) (a) of the Federal Constitution, being unreasonable. This shows that the motive of the legislature as expressed in the UUCA is unreasonable and unconstitutional in the court's view.

A careful study of the above judicial decisions reveals that the initial position was that issue relating to the motive behind a legislative action is not justiciable. This was the position irrespective of the legislative actions involved. However, the position seems to have changed recently as the courts, especially the Federal Court, have introduced the test of reasonableness of the legislative action especially where it relates to law making which restricts the rights of the people.

$\begin{array}{ll}52 & {[2011] 6 \text { MLJ } 507 .} \\ 53 & {[1977] 2 \text { MLJ } 187 .}\end{array}$




\section{CONCLUSION}

From the foregoing analysis, the courts in Malaysia have largely adopted 'a hands tied approach' to matters which border on the validity of legislative proceedings. The courts have generally and technically bowed down to legislative actions on many occasions, refusing to exercise judicial review power. The regularity or otherwise of the procedure or proceedings leading to such actions is not the business of the courts. It has been regarded as sacrosanct and not justiciable. The reason for this approach is that the constitutional framework has denied the courts power to interfere in matters which seek to challenge the validity or otherwise of the legislative proceedings. Also, the courts felt that matters on legislative proceedings involve high political undertones which are not fit for courts' interventions. So, it seems the courts do not want to do anything that would result in confrontation between the judiciary and the legislature.

Based on the above premise, the courts seem not to have a coherent approach to resolving disputes brought before it by legislative members to challenge certain legislative proceedings. So, with regard to issue of suspension of legislative members from the House, the courts exercised judicial review power as it was held that it affected the legal rights of the member concerned and hence justiciable. However, in a situation where the issue relates to suspension from House committees, the court would refuse to intervene in this regard. Where the matter had to do with removal from committees or as principal members of the House such as the speaker, the court has refused the exercise of judicial review power on this issue. The courts initially also decided that the issue of whether a person is disqualified from the house is not for the courts to decide as it is not justiciable. However, recent decisions do not favour this approach. Also, the courts have held the view that injunction cannot lie against the proceeding of the legislature. More so, the initial reaction of the courts to expediency of legislative actions was that the courts would not question the motive for legislative actions. However, recent courts' decisions felt that the earlier position was too open-ended as legislature used this opportunity of courts' non-intervention to enact laws which affect the individual fundamental rights. Consequently, the courts held the view that any restriction on the fundamental rights of the people must be reasonable and justifiable. So, there is the need to shape the legal framework in such a way that would allow courts' intervention in deserving circumstances in the interest of justice, fair play, 
constitutionalism and democracy. The persistent hands tied approach is not reasonably justifiable in the spirit of free speech, open space in government, accountability and probity. The approach may not promote real democratic debate in parliament as a legislator may be apprehensive of a particular position he has taken on a matter. As it is, the court seems to be forcing its way to make necessary incursion. This may lead to collision course or crisis between the judiciary and the law makers as sometimes the legislature may not be favourably disposed to courts' review of legislative processes. 